\title{
Heroism and Hypocrisy: Seeing Our Reflection with 2020 Vision
}

\author{
Ira Byock, MD, FAAHPM, Editorial Board Member ${ }^{1,2}$
}

$\mathbf{P}$ EOPLE WHO WORK in the field of hospice and palliative care are accustomed to being misunderstood. At parties or on planes, when people ask and we tell them what we do, their emotions range from "Bless your heart" to "I don't know how you do that." Most of the time, the conversation mercifully moves on to other subjects. In practicing hospitalbased palliative care, "The H Word" is something referring colleagues ask us to avoid when we introduce ourselves to a patient and family. "They're not ready for hospice," they explain, and do not want us to be stained by that brush. Indeed, based on marketing research it commissioned, the Center to Advance Palliative Care has advised palliative care providers to eschew the word "hospice" in describing what we do. ${ }^{1}$

But you can sense a shift in the cultural landscape. Amid the COVID-19 pandemic, hospice's new H Word is Hero! Stripped of the illusion of security, the public sees the immediate and enduring value of palliative care, home health care, nursing home care, and hospice. I hope we own it. Let us refrain from reflexively deflecting the compliments. It is culturally important for our field to be recognized as heroes.

I have often thought our work was analogous to the vocation of firemen. In circumstances of serious illness, dying, and grief_-from which reasonable people are running away-we rush in. We willingly walk close to the fire. We feel the heat and accept the risk of being personally singed. In calling our work heroic, the public gives voice to the values and personal attributes that human beings hold highest. You can hear it in the nightly boisterous celebrations for health care workers, the singing and horns and applause and, here in Missoula, Mont., the 8 pm howls. These are healthy expressions of gratitude. Own them.

Of course, nothing in tumultuous 2020 is simple. For all the plaudits coming our way, the searing honesty of this most terrible year also reveals our blind spots, flaws, and failures. The pandemic has demonstrated glaring health disparities suffered by people of color, people who are poor, and those who live or work in crowded conditions. They have always been there, well studied and documented, but somehow tolerated. In the wake of videotaped police killings of black people, we have been forced to reckon with endemic racism.
Every industry and profession, including our own, are being called to examine structural and cultural biases and the inequities we impose on black, Latinx, and immigrant communities, as well as transgender people. We have been warned that such examinations will be uncomfortableindeed must be uncomfortable-if they are real. ${ }^{2}$

Health care organizations are earnestly stepping up. By last spring, every organization's board and senior management were developing substantive position papers and diversity, equity, and inclusion plans. A steady stream of health care webinars, panel discussions, and podcasts are calling attention to assumptions and patterns of clinical practice that reflect implicit biases.

These efforts are long overdue and entirely worthwhile. They are also insufficient. We have yet to witness an unblinking assessment of ubiquitous prejudicial business practices that are rooted in race, ethnicity, or gender. Health care's sustaining contribution to the social disease of our time lies in the ways we treat and compensate direct care workers. About 4.5 million home health aides, personal care aides, and nursing assistants in the United States form the backbone of our health care system. Many work for home care, nursing homes, and hospice companies. There are countless heroes among them who richly deserve to be held up as examples. However, at least until the pandemic, they were largely unseen. That needs to change.

Direct care workers are among the most poorly paid of any occupations in America, despite doing some of the hardest jobs in health care. In 2018, wages for those providing intimate care for cleansing, toileting, dressing, and feeding frail elders and people with disabilities ranged from a median of $\$ 11.55$ hourly ( $\$ 24,000$ annual) for personal care aides to $\$ 14.25$ hourly (\$29,660 annual) for certified nursing assistants. ${ }^{3,4}$

Corporate executives and legislators debate the complexities of determining a living wage. But this is not particle physics and reasonable estimations will suffice. There is even an app for that. M.I.T. researchers have developed a Living Wage Calculator. ${ }^{5}$ Regional hourly living wages for a family with two children and two working adults are estimated to be \$16.96 in Missoula, \$20.47 in Los Angeles, and \$22.56 in

\footnotetext{
${ }^{1}$ Institute for Human Caring, Providence St. Joseph Health, Gardena, California, USA.

${ }^{2}$ Geisel School of Medicine at Dartmouth, Hanover, New Hampshire, USA.
}

(C) Ira Byock 2020; Published by Mary Ann Liebert, Inc. This Open Access article is distributed under the terms of the Creative Commons Attribution Noncommercial License (http://creativecommons.org/licenses/by-nc/4.0/) which permits any noncommercial use, distribution, and reproduction in any medium, provided the original author(s) and the source are credited. 
New York City. For a single parent with two children, comparable living wages are $\$ 31.10$ hourly in Missoula, $\$ 38.06$ in Los Angeles, and \$42.33 in New York.

Nearly a fifth of direct care workers are officially poor, living below the federal poverty threshold for a family. Fiftythree percent of these working adults require public assistance, including 26\% who rely on Medicaid and 24\% who receive supplemental nutrition assistance. ${ }^{6}$

Even before COVID-19, direct care workers had among the highest rates of on-the-job injuries of any occupation. In this pandemic, these heroes have often had to enter the homes and congregate living facilities of infected patients without sufficient masks, gowns, and gloves, thereby putting themselves and their own families at high risk. Few have been accorded hazard pay. Few have sick leave benefits. This is no way to treat heroes.

Because of the circumstances in which they live and work, direct care workers are sometimes unwitting vectors of the virus. Their homes tend to be crowded. Many can only find part-time positions-a feature that helps companies to limit benefits - and must, therefore, work at two or more locations to provide for their families. As a result, they are prone to transmit the virus to the multiple workplaces in which they give intimate care.

Is this tragedy the result of racism and sexism in health care? The short answer is yes. It is no coincidence that $>85 \%$ of direct care workers are women, nearly $60 \%$ are people of color and more than a quarter are immigrants. ${ }^{7}$ That does not mean that the corporate executives and bureaucratic managers who determine wages, hiring, and employment practices are overtly racist. Accepting this distinction requires understanding the omnipresent influence on well-meaning individuals' attitudes and actions of the unending need to turn a profit from caring for frail, disabled, and dying Americans. In the "no margin, no mission" mindset of America's health care culture, leaders believe they cannot afford to pay a living wage to all employees, that doing so would decrease their company's EBITDA (earnings before interest, taxes, depreciation, and amortization), damage stock prices and risk lowering their bond ratings. Within $\mathrm{C}$-suites, any disagreement with this assumption is perceived as naive. Leaders are not intentionally making decisions that harm women or people of color. The structural nature of racism and sexism renders the intentions of individual company executives irrelevant.

The social upheavals of the pandemic, Black Lives Matter, and pervasive racism and sexism represent opportunities to challenge long-held assumptions and reset expectations. The truest indicator of any organization's moral compass is not found in its mission or vision, but in its budget, particularly the line items devoted to personnel salary and benefits. Boards of directors of health care companies, including both for-profit and not-for-profit entities, must require that all workers are paid a living wage and treated fairly, regardless of the opinion of the market or bond rating agencies. Each company's diversity, equity, and inclusion policy should mandate transparent public reporting of direct care workers' median wages, benefits, and annual turnover rates, along with the proportion of part-time to full-time employees. In addition to days cash on hand, boards should require leadership to report days protective equipment on hand. Sick leave, family leave, and hazard pay for working in hazardous conditions should be required benefits of employment.

Unless and until we stop making excuses for our mistreatment of the least powerful among us, the health care industry will be unable to own its ignominious contributions to endemic racism and sexism that have been part of sustaining this pandemic. This statement is at once an indictment and confession. No individual of seniority and years in health care can credibly deny complicity, if only in acquiescence to the status quo.

If we are to authentically address issues of diversity, equity and inclusion, we must cut the chains of margin-driven care and model the values we espouse. Only then will we be able to chart a course to a more healthy and equitable future.

There is an $\mathrm{H}$ word for health care company leaders who call their frontline caregivers heroes, while neglecting to protect their health or pay them a living wage: Hypocrites.

\section{References}

1. Meier DE, Morgan L, Back T: More on messaging: Getting the care to the patients. Webinar presented at the: Center to Advance Palliative Care; January 21, 2020.

2. Johnson V, Edmonds J: I see you. I hear you. And I ache for you. https://www.instituteforhumancaring.org/Hear-Me-Now/ Washington/-I-see-you-I-hear-you-And-I-ache-for-you-8-46 .aspx (Last accessed August 24, 2020).

3. U.S. Bureau of Labor Statistics: Home health aides and personal care aides. Occupational outlook handbook. https://www.bls .gov/ooh/healthcare/home-health-aides-and-personal-care-aides .htm. 2020. (Last accessed August 24, 2020.)

4. U.S. Bureau of Labor Statistics: Nursing Assistants and Orderlies. Occupational Outlook Handbook. https://www.bls.gov/ ooh/healthcare/nursing-assistants.htm. 2020. (Last accessed August 24, 2020).

5. Glasmeier AK; Massachusetts Institute of Technology: Living wage calculator. https://livingwage.mit.edu 2020. (Last accessed August 24, 2020).

6. Kirschner KL, Iezzoni LI, Shah T: The invisible COVID workforce: Direct care workers for those with disabilities. The Commonwealth Fund. https://www.commonwealthfund.org/ blog/2020/invisible-covid-workforce-direct-care-workersthose-disabilities (Last accessed August 24, 2020).

7. Espinoza R: Immigrants and the direct care workforce: Paraprofessional Healthcare Institute; 2017:14. https://phi national.org/wp-content/uploads/2017/06/Immigrants-andthe-Direct-Care-Workforce-PHI-June-2017.pdf (Last accessed August 24, 2020.)

Address correspondence to: Ira Byock, MD, FAAHPM Institute for Human Caring Providence St. Joseph Health 879 W. 190th Street, Suite 1000 Gardena, CA 90248 USA

E-mail: ira.byock@gmail.com 